\title{
Notes on the Use of Glycerine for the Alleviation of the Pain Reaction in the Subcutaneous Adminstration of Sodium Hydnocarpate.
}

\author{
J. T. JACKSON.
}

$\checkmark \mathrm{HE}$ use of glycerine has been advocated by the author ${ }^{1}$ as an addition to solutions of sodium hydnocarpate to be injected by the method of subcutaneous infiltration in the treatment of leprosy for the purpose of reducing the pain reaction commonly occurring when sodium hydnocarpate solutions alone are used.

Glycerine has been used for this purpose at the Bankura Leprosy Home for some time with good results. Not always has there been complete elimination of pain, but the pain reaction in most cases has been considerably reduced and it is possible that it could be almost entirely eliminated if the strength of the glycerine solution is properly regulated.

On account of the soothing effect which glycerine has upon irritated tissues generally and its good penetrating power, one would expect that its addition to the sodium hydnocarpate solution to be injected would be an advantage. The addition would in this way be expected also to increase the absorbing power of the tissues and thereby shorten the time of the pain reaction (if any) resulting from such an injection.

The strength of the solution generally employed has been 2.5 c.c. of pure double distilled glycerine to 100 c.c. of 3 per cent. sodium hydnocarpate solution containing 0.5 per cent. of carbolic acid. Full particulars for the preparation of the solution are given in the original article.

These notes are an account of an experiment carried out at the same time and in the same way as the tests made on the pain reaction resulting from the injection of different fractions of sodium hydnocarpate in solutions of varying Hydrogen-ion concentration ${ }^{2}$. When the first two sets of series of courses of injections in these experiments had been completed, a further set of two series of courses was carried out by adding glycerine to the various solutions of sodium hydnocarpate to bring them to the strength mentioned above. The "Pain Factor" was then again determined for each fraction of sodium hydnocarpate in the same way as before and the resulting observations compared with those 
TABLE

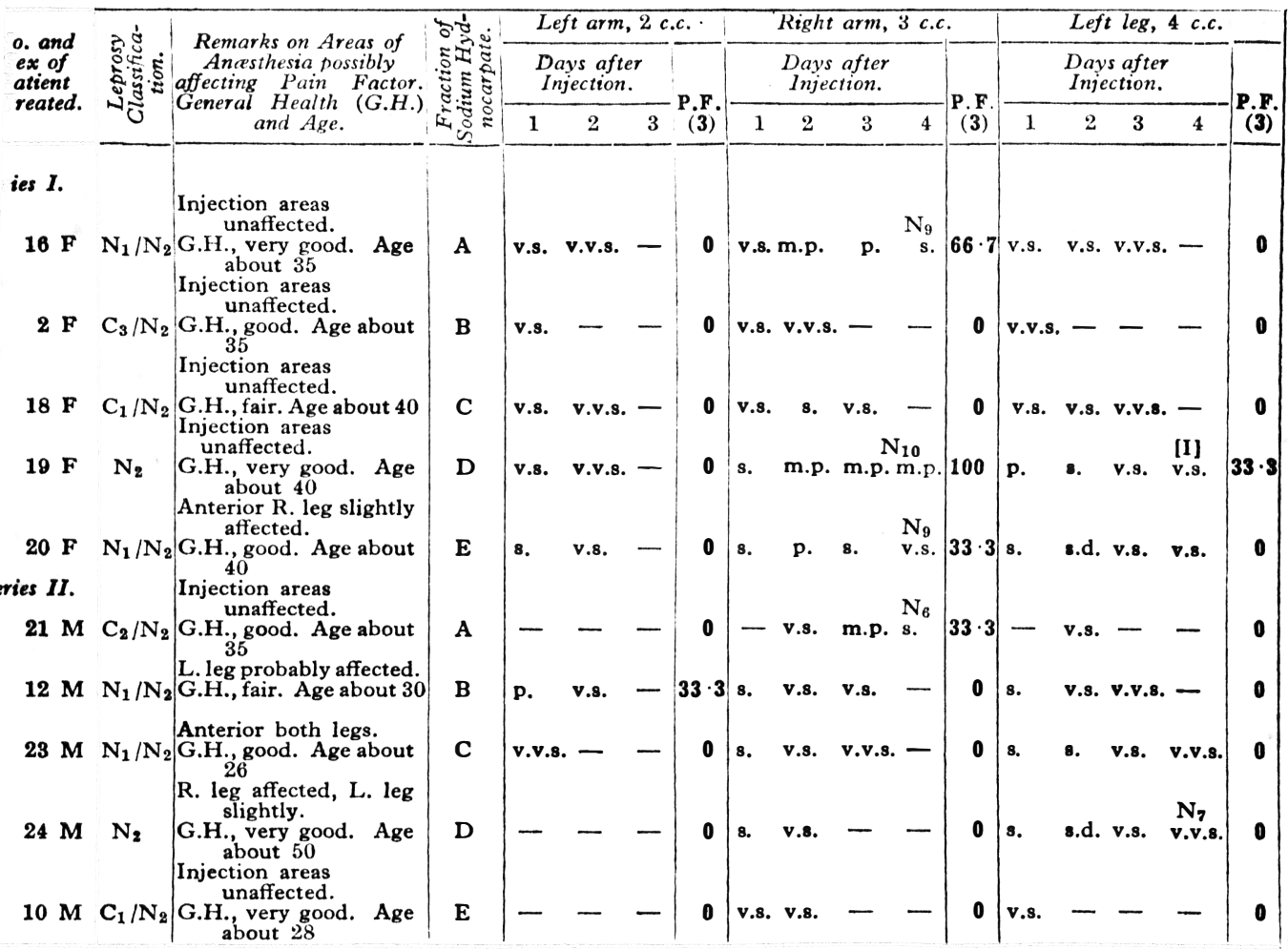

$\mathrm{T}_{\mathrm{ABL}}$

\begin{tabular}{|c|c|c|c|c|c|c|c|c|c|c|c|c|c|c|c|c|c|}
\hline \multirow{3}{*}{$\begin{array}{l}\text { No. and } \\
\text { Sex of } \\
\text { Patient } \\
\text { Treated. }\end{array}$} & \multirow{3}{*}{ 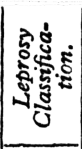 } & \multirow{3}{*}{$\begin{array}{c}\text { Remarks on Areas of } \\
\text { Ancesthesia possibly } \\
\text { affecting Pain Factor. } \\
\text { Genernl Health (G.H.) } \\
\text { and Age. }\end{array}$} & \multirow{3}{*}{ 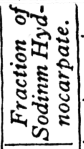 } & \multicolumn{4}{|c|}{ Left arm, 2 c.c. } & \multicolumn{5}{|c|}{ Right arm, 3 c.c. } & \multicolumn{5}{|c|}{ Left leg, 4 c.c. } \\
\hline & & & & \multicolumn{3}{|c|}{$\begin{array}{l}\text { Days after } \\
\text { Injection. }\end{array}$} & \multirow{2}{*}{ P.F. } & \multicolumn{4}{|c|}{$\begin{array}{l}\text { Days after } \\
\text { Injection. }\end{array}$} & \multirow{2}{*}{ P.F. } & \multicolumn{4}{|c|}{$\begin{array}{l}\text { Days after } \\
\text { lnjection. }\end{array}$} & \multirow{2}{*}{ P.F. } \\
\hline & & & & 1 & 2 & 3 & & 1 & 2 & 3 & 4 & & 1 & 2 & 3 & 4 & \\
\hline ies $I$. & & $\begin{array}{c}\text { Injection areas } \\
\text { unaffected. }\end{array}$ & & & & & & & & & & & & & & & \\
\hline $16 \mathrm{~F}$ & $\mathbf{N}_{1} / \mathbf{N}_{2}$ & $\begin{array}{l}\text { G.H., very good. Age } \\
\text { about } 35 \\
\text { Injection areas } \\
\text { unaffected. }\end{array}$ & $\mathbf{A}$ & v.v.s. & v.v.s. & - & 0 & v.v.s. & v.8. & - & - & 0 & v.v.8. & - & - & - & 0 \\
\hline $2 \mathrm{~F}$ & $\mathrm{C}_{3} / \mathrm{N}_{2}$ & $\begin{array}{l}\text { G.H., good. Age about } \\
35 \\
\text { Injection areas } \\
\text { unaffected. }\end{array}$ & B & v.v.s. & - & - & 0 & v.v.s. & . - & - & - & 0 & v.v.s. & - & - & - & 0 \\
\hline $18 \mathrm{~F}$ & $\mathrm{C}_{1} / \mathrm{N}_{2}$ & $\begin{array}{l}\text { G.H., fair. Age about } 40 \\
\text { Injection areas } \\
\text { unaffected. }\end{array}$ & C & v.8. & v.v.8. & - & 0 & v.v.s. & v.v.s. & v v.s. & - & 0 & v.v.8. & - & - & - & 0 \\
\hline $19 \mathrm{~F}$ & $\mathbf{N}_{2}$ & $\begin{array}{l}\text { G.H., very good. Age } \\
\text { about } 40 \\
\text { Anterior R. leg slightly } \\
\text { affected. }\end{array}$ & D & - & - & - & 0 & v.v.s. & . - & - & - & 0 & v.v.8. & - & - & - & 0 \\
\hline $\begin{array}{l}20 \mathrm{~F} \\
\text { ies } I I .\end{array}$ & $\mathrm{N}_{1} / \mathrm{N}_{2}$ & G.H., good. Age about & E & v.8. & v.v.8. & - & 0 & v.8. & v.8. & V.v.8. & - & 0 & v.v.s. & - & - & - & 0 \\
\hline $21 \mathrm{M}$ & $\mathrm{C}_{2} / \mathrm{N}_{2}$ & $\begin{array}{l}\text { Injection areas } \\
\text { unaffected. } \\
\text { G.H., good. Age about } \\
\mathbf{3 5}\end{array}$ & $\mathbf{A}$ & v.v.8. & - & - & 0 & v.v.8. & . - & - & - & 0 & v.v.s. & v.v.8. & - & - & 0 \\
\hline $12 M$ & $\mathrm{~N}_{1} / \mathrm{N}_{2}$ & $\begin{array}{l}\text { L. leg probably affected. } \\
\text { G.H., fair. Age about } 30 \\
\text { Anterior both legs. }\end{array}$ & B & v.8. v. & . $7.8 . v$ & 7.v.8. & 0 & v.B. & V.8.d. & v.V.8. & - & 0 & v.v.s. & - & - & - & 0 \\
\hline $23 \mathrm{M}$ & $\mathrm{N}_{1} / \mathrm{N}_{2}$ & $\begin{array}{l}\text { G.H., good. Age about } \\
26 \\
\text { R. leg affected, L. leg }\end{array}$ & C & - & - & - & 0 & v.8. & v.v.8. & - & 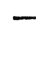 & 0 & v.v.s. & - & - & - & 0 \\
\hline $24 M$ & $\mathrm{~N}_{2}$ & $\begin{array}{l}\text { G.H., very good. Age } \\
50 \\
\text { Injection areas }\end{array}$ & D & - & 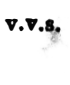 & - & 0 & 7.8. & v.8.d. & $\nabla .7 .8$. & - & 0 & v.8. & v.7.8. & v.v.8. & - & 0 \\
\hline $10 \mathrm{M}$ & $\mathrm{C}_{1} / \mathrm{N}_{2} \mid$ & $\begin{array}{l}\text { G.H. very good. Age } \\
\text { about } 28\end{array}$ & $\mathbf{E}$ & - & - & - & 0 & - & - & - & - & 0 & - & - & - & - & 0 \\
\hline
\end{tabular}




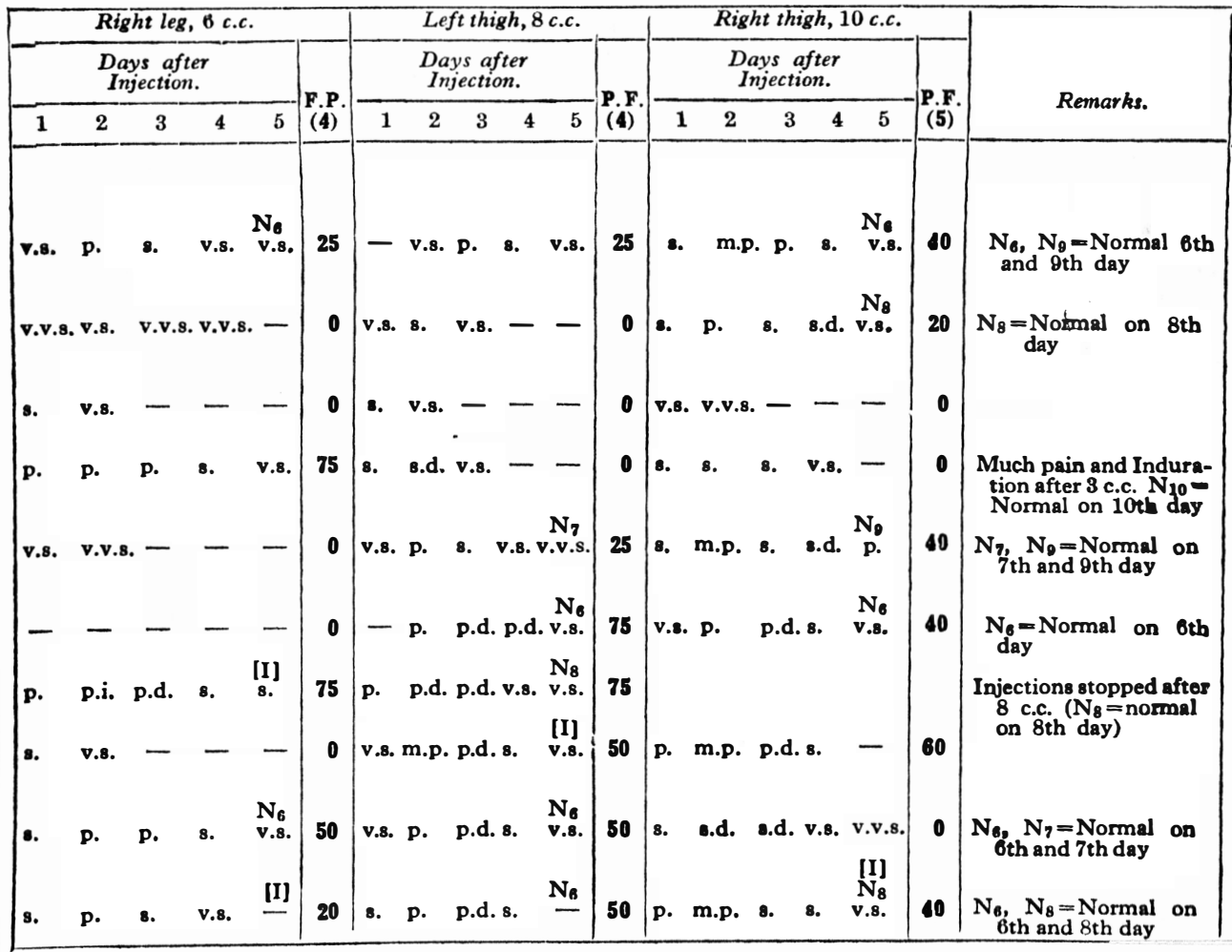

I.

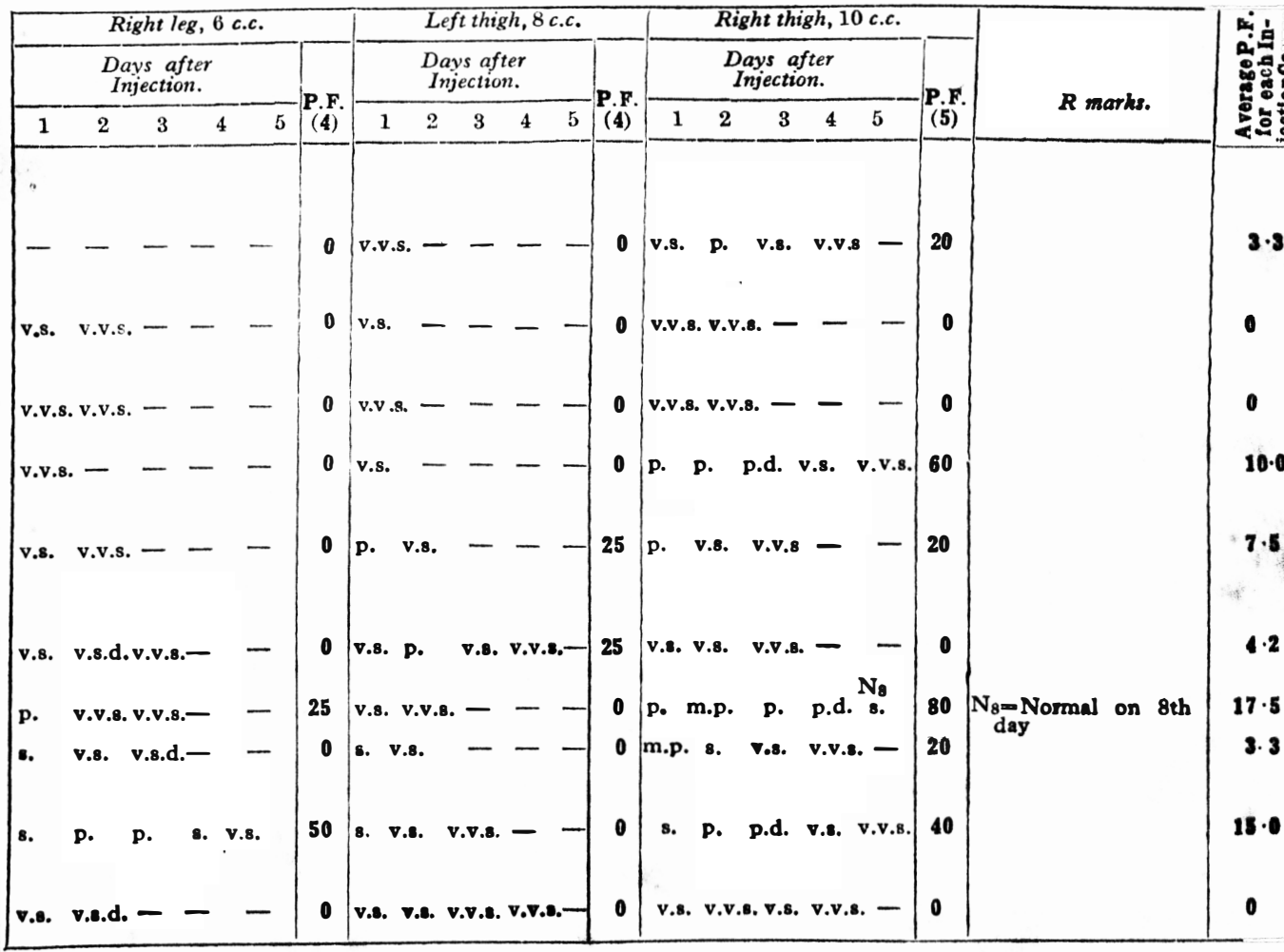


obtained on the same patients when previously injected with the solutions without the glycerine addition.

Experimental.-The fractions of sodium hydnocarpate used were those marked A, B, C, D, E; particulars of which are given in the previous paper'.

The patients selected generally, as far as possible, were those who had had the highest pain reaction when using sodium hydnocarpate alone. The designation numbers of the patients in the Tables here given are the same as those used in the Tables published in the last issue of Leprosy Review.

The period covering the injections was from early October to early November, 1929, immediately following the completion of the tests made with the sodium hydnocarpate solutions alone, so that as far as possible, the other varying factors influencing the pain reaction were kept as constant as possible for comparative purposes.

The observations were made and the Pain Factor (P.F.) calculated in the same way for each course of injections as previously described ${ }^{2}$. The records thus obtained are given in the Tables on pages 122 and 123 .

Table I.-The particulars here given are the observations made on the patients selected for treatment with the glycerine solution, but in this case when treated with the solutions of sodium hydnocarpate employed alone. The particulars are taken from Tables I and II of the previous paper ${ }^{2}$.

Table II.-Here are recorded the observations made on the same patients as in Table I above using the same fractions

TABle III.

Comparing "Pain Factor" of Sodium Hydnocarpate Solutions with AND WITHOUT GLYCERINE.

\begin{tabular}{|c|c|c|c|c|c|c|}
\hline \multirow{2}{*}{$\begin{array}{c}\text { Fraction of } \\
\text { Sodium } \\
\text { Hydnocarpate. }\end{array}$} & \multirow{2}{*}{\begin{tabular}{|c|} 
Mean \\
P.F.from \\
Table IV. \\
(See \\
previous \\
paper).
\end{tabular}} & \multicolumn{3}{|c|}{$\begin{array}{c}\text { P.F. of Solutions with Glycerine- } \\
\text { Table II. }\end{array}$} & \multirow[b]{2}{*}{$\begin{array}{c}\text { Decrease } \\
\text { in Mean } \\
\text { P.F. }\end{array}$} & \multirow{2}{*}{$\begin{array}{c}\text { Per cent. } \\
\text { Decrease } \\
\text { in P.F. }\end{array}$} \\
\hline & & Series $I$. & Series II. & $\begin{array}{l}\text { Mean } \\
\text { P.F. }\end{array}$ & & \\
\hline $\begin{array}{l}\text { A. } \\
\text { B. } \\
\text { C. } \\
\text { D. } \\
\text { E." }\end{array}$ & $\begin{array}{r}13 \cdot 4 \\
15 \cdot 9 \\
3 \cdot 1 \\
23 \cdot 3 \\
12 \cdot 2 \\
\end{array}$ & $\begin{array}{c}3 \cdot 3 \\
0 \\
0 \\
10 \cdot 0 \\
7 \cdot 5\end{array}$ & $\begin{array}{r}4 \cdot 2 \\
17 \cdot 5 \\
3 \cdot 3 \\
15 \cdot 0 \\
0\end{array}$ & $\begin{array}{r}3 \cdot 8 \\
8 \cdot 8 \\
1 \cdot 7 \\
12 \cdot 5 \\
3 \cdot 8\end{array}$ & $\begin{array}{r}9 \cdot 6 \\
7 \cdot 1 \\
1 \cdot 4 \\
10 \cdot 8 \\
8 \cdot 4 \\
\end{array}$ & $\begin{array}{l}71 \cdot 6 \\
44 \cdot 7 \\
45 \cdot 2 \\
46 \cdot 4 \\
68 \cdot 9\end{array}$ \\
\hline
\end{tabular}

Average Percentage Decrease in P.F $=55.4$.

- Commercial Product. 
of sodium hydnocarpate solution but with the addition of glycerine to each solution in the same strength as given above.

Table III.- In this Table a comparison is made between

(a) the Mean Pain Factor, as previously determined for the five fractions of sodium hydnocarpate examined without any addition of glycerine, and

(b) the Mean P.F. after the addition of glycerine. As a basis for comparison, the Mean P.F. given in column two is that found for the samples of sodium hydnocarpate as recorded in Table IV. of the article already referred to.

\section{Conclusions.}

That the use of glycerine as an addition to solutions of sodium hydnocarpate for subcutaneous injections is undoubtedly of benefit in reducing the pain reaction usually following such injections.

From Table III above it will be seen that the average percentage decrease in the "Pain Factor" is 55.4; the minimum decrease being 44.7 per cent. and the maximum 71.6 per cent. There is no doubt that this figure would be higher still if the strength of the glycerine solution is increased. It was not possible at the time to carry out further comparative tests with higher percentages of glycerine.

As the pain reaction following the injection of solutions of sodium hydnocarpate has been shown to have no direct relationship with the Hydrogen-ion concentrations of these solutions for the range of $p \mathrm{H}$ examined ${ }^{2}$, the author suggests that the varying results obtained with different batches and products of sodium hydnocarpate, so far as their pain reaction is concerned, can be overcome and considerably reduced by the addition of glycerine when injections are to be made by the subcutaneous infiltration method.

REFERENCES.

'Jackson, J. T. " Alleviation of Pain following the Administration of "Alepol' Subcutaneously," "The Superintendent," No. 16, Aug., 1929, and "Leprosy Notes," No. 7, 1929.

"Jackson, J. T. "Some Observations on the Influence of the Hydrogen-ion Concentration on the Pain Reaction in the Administration of Sodium Hydnocarpate Solutions by Subcutaneous Infiltration." Leprosy Review, Vol. III, No. 2, 1932. 